\title{
Annulment of Marriage due to Falsification of Husband's Identity in Polygamous Marriage
}

\author{
Muhammad Muladi ${ }^{1}$, Evita Isretno Israhadi ${ }^{2}$ \\ University of Borobudur ${ }^{1,2}$ \\ \{muhammadunboro@gmail.com¹, evita_isretno@borobudur.ac.id ${ }^{2}$ \}
}

\begin{abstract}
In a marriage, the ideal condition of a husband or wife cannot be fully obtained. The study used normative juridical, namely reviewing the evidentiary process and legal considerations used by judges. This study's result is that the Applicant has passed away so that Salijo is a widower and can remarry the Respondent. But Salijo, until his death, the Applicant is still alive and in good health, fresh and fit. The Applicant lives with his children and grandchildren.
\end{abstract}

Keywords: Annulment of Marriage; Identity Forgery; Polygamy

\section{Introduction}

Every married couple always wants their marriage to last only once in a lifetime. There is illustrated in Article 3 paragraph (1) of Law No. 1 of 1974, which is that a man can only have a wife, and a woman can only have a husband. In Article 3 paragraph (1), a marriage adheres to the principle of monogamy. However, the Law of Marriage as contained in the Law on Marriage and Compilation of Islamic Law provides an exception to a husband who wants to have more than one wife who must obtain permission from the Court and meet the conditions to be able to marry more than one. If a man and a woman have agreed to perform the marriage, it means that they have promised to obey and comply with the laws applicable in marriage, and the rules apply as long as the marriage lasts, or the marriage breaks up (Soemiyati, 1996:10).

In a marriage, the ideal condition of a husband or wife cannot be fully obtained. There will not be an obstacle if the husband and wife agree to sail the household ark with mental readiness and mutual understanding between the two. But the in reality society, we often find polygamy challenging to do, so the tendency to solve polygamy by silent and dishonest. Dishonesty here is done, among others, using a false identity to the registrar of marriage, where Mereka claimed to be a virgin even though legally still the husband of another woman.

Usually, the forgery is contained in authentic letters and deed in the form of identity of the perpetrator but rarely entangled by the law and challenging to prove, and this happens because of several factors, namely the lack of evidence, well-planned actions, witnesses do not know the acts committed by the perpetrator and the desire to do polygamy where the perpetrator does not want to tell the first wife. In connection with the above problems, Law No. 1 of 1974 does not explain in detail the annulment of marriage due to identity forgery. Still, the Marriage Law only describes marriage's dissolution because of a misperception against the husband or 
wife (feel cheated or there is an element of fraud) committed by one of the parties can apply for annulment of marriage to the Court of Religion.

In Article2 of Law No. 1 of 1974, it is also explained that:

a. Marriage is valid if it is performed according to the laws of each religion and its beliefs.

b. Each marriage is recorded according to the prevailing laws and regulations.

If seen from Article 2 paragraph (1), it can be explained that marriage is considered valid if done according to their respective laws and beliefs because it is a form of protection for the parties. But in practice, some perform marriages that do not meet the pillars or conditions of marriage, and there is a misjecture between the two parties after the wedding is held. As the author is careful that Respondent I has forged his identity to carry out Marriage with Respondent II, that Respondent I already has a wife, Respondent I claimed the status of single to Respondent II and his family. So that without his wife's knowledge, Respondent I married Respondent II. After the marriage, respondent II and the KUA party know that Respondent I has had a wife. Finally, the Applicant's KUA party applies for the annulment of Marriage to the Klaten Religious Court.

From the case, to protect the sacredness of marriage and obtain legal certainty, a wedding can be the annulment of marriage so that the marriage's existence harms no party. Thus an unqualified marriage or marriage harmony or marriage is conducted because of fraud of one of the parties, and then the marriage can be annulled.

Annulment of Marriage, other than due to marriage that does not meet the conditions of marriage, can also be caused by marriage is carried out because of an element of fraud or misconceptions about the husband or wife as stipulated in Article 27 paragraph (2) law No. 1 of 1974 and Article 72 paragraph (2) Compilation of Islamic Law that states that a husband or wife can apply for annulment of marriage if at the time of marriage there is a misconception about the husband or wife. A court ruling can only do the dissolution of marriage. With the court ruling that annulled the wedding, the union that has occurred is considered never existed. Although marriage is deemed to have never existed, it does not necessarily eliminate the marriage's legal consequences that were once performed.

The Court's decision is a final-stage decision, whether the marriage is annulled or still legalized, of course through consideration of the benefits made by the Judge. Therefore, a good judge's decision will undoubtedly fulfill 3 (three) elements/aspects at once in a balanced manner that provides legal certainty, a sense of justice, and benefits for the parties and society (Arto, 1996: 35). The Court's decision on annulment of an invalid marriage can have legal consequences for both husband and wife and their respective families as contained in the national law, namely the Marriage Law No. 1 of 1974 and the Compilation of Islamic Law (KHI), where the husband and wife return to their original state or among them as if they had never held a marriage. In addition to those stated above, the annulment of marriage also has a significant meaning. The annulled marriage will have an impact not only for the couple but also on the parties related to the wedding, such as property in marriage as stipulated in Article 35 of Law No. 1 of 1974. And as a result of the forgery of marriage, it does not apply retroactively to the parties in Article 28 paragraph (2) Law No. 1 the year 1974 and Article 75 Compilation of Islamic Law.

However, suppose the annulment of his marriage is due to the cause of identity forgery, where identity forgery is a form of a material violation, not formil. In that case, the consequences are also content. And the material result is only an affidavit in the form of a ruling of the Court of Religion that the marriage was annulled. However, suppose the violation occurs because of the prohibition of formal. In that case, the existing wedding can be canceled by itself or considered never to exist so that there are consequences that arise that do not get 
legal protection. So as part of the purpose of identity clarity is the existence of legal clarity against people or individuals to maintain their rights and obligations in the law. To strengthen the identity clarity of the need for population administration, in Law No.23 of 2006, article 1 paragraph (1) explains: "Population Administration is a series of structuring and controlling activities in the issuance of documents and Population Data through Population Registration, Civil Registration, management of Population Administration information and utilization of the results for public services and other sector development." Efforts to protect individuals have required a clear identity which is recorded in the Residence Document that has been regulated in Law No. 23 of 2006 article 1 paragraph (8) explains: "Residence Document is an official document issued by the Implementing Agency that has the force of law as an authentic evidence tool resulting from the service of Population Registration and Civil Registration."

Also, perpetrators who falsify authentic letters listed can be penalized with the threat of imprisonment contained in Article 263 paragraph (2) of the Criminal Code concerning counterfeiters with a maximum prison sentence of six years and Article 266 paragraphs (1) and (2) of the Criminal Code on making and ordering forgery of authentic letters and deed with a maximum prison sentence of seven years. Simultaneously, the provisions of the law can trap husbands who remarry without the first wife's permission (second or third). One of them is Article 279 of the Criminal Code, which reads as follows:

a. Threatened with a maximum prison sentence of five years:

1. Whoever has a marriage when he knows that his Marriage or Marriage is a valid barrier to it;

2. Whoever holds a marriage knowing that the Marriage or Marriage of the other party becomes a barrier to it.

b. If the one who commits an act under Article 1 points a hides to the other party that the existing marriage becomes a valid barrier, it is threatened with a maximum imprisonment of seven years.

As stated in Article 49 of Law No. 3 of 2006 concerning Amendments to Law No. 7 of 1989 regarding Religious Justice says that the Religious Court has to accept, examine and adjudicate the case brought against him. In reviewing a case, the Judge must have evidence submitted to decide a claim. The Judge's legal basis in the Religious Court in determining the patient must also be under Islamic Law and Law. Therefore, to carry out a marriage before the marriage contract occurs, there is first examining the terms and pillars of marriage, both determined by religion and the Marriage Act.

\section{Methodology}

This research is normative juridical, namely reviewing the evidentiary process and legal considerations used by judges. Normative law research is literature research, which is research on secondary data. Secondary data has a scope that includes personal letters, books, up to official documents issued by the government. The author uses a normative juridical method approach because what is examined is the legal aspect, the legal method of resolving the dispute process of annulment of marriage due to the male party's fraud. So it can be known the legal position of deciding the dispute annulment of marriage because of fraud committed by the male party.

A normative legal approach is an approach that is done based on the primary raw material, studying theoretical matters related to legal principles, legal conceptions, legal views and doctrines, regulations, and legal systems using secondary data, the antenna principles, rules, 
norms, and the rule of law contained in legislation and other practices by studying books, legislation and other documents related to research. Empirical law is an approach done in the field by collecting information employing observations and interviews with sources related to the problems discussed in this study.

\section{Result and Discussion}

\subsection{The Process of Proof and Legal Consideration in Handling Cases of Marriage Cancellation Due to Identity Forgery at the Klaten Religious Court}

Identity Forgery done by the Bride-to-be is a very desirable thing by every prospective married couple. Islam strongly advocates marriage; this advice has been the prophet's sunnah since time immemorial and should also be followed by generations to come. Because one of the purposes of marriage is to honor the sunnah Rasulullah s.a.w. he denounced those who promised to fast every day, wake up and worship every night, and not marry. Identity forgery will not occur if the marriage is performed following the applicable procedures. A good marriage is a marriage between a man and a woman who are equally religious, moral, and purposeful, in addition to love and sincerity of heart. Under the auspices of harmony, the husband and wife's life will be peaceful, full of love and affection, the family will be happy, and the children will prosper. In the Islamic view, such a family life will not materialize perfectly unless the husband and wife hold fast to Islam's teachings.

If the two's religion is different, then there will be various difficulties in the family, and in the process of licensing, the marriage will be difficult. Also, it will find problems in the implementation of worship, child education, the construction of religious traditions, and others. Article 71 paragraph 1 Compilation of Islamic Law mentioned that a marriage could be annulled if a husband commits polygamy without permission from the Court of Religion. Article 72 paragraph 2 Compilation of Islamic Law mentions a husband or wife can apply for annulment of marriage if there is fraud or misreception about the husband or wife at the time of marriage. This is the basis and legal basis for the abolition of marriage on the grounds of identity forgery.

But the in reality society, we often find the settlement of polygamy challenging to do, so the tendency to solve polygamy quietly and dishonestly. Dishonesty here is done, among others, using false identities to the registrar of marriage, where they claim to be virgins while legally still the husband of another woman. As the case above shows, the Applicant with Salijo held a wedding and was blessed with five children in his marriage. Salijo was married to the Applicant until his death; since Salijo died, the Applicant as a legal wife is not married again or still widowed. The Applicant with Salijo is still in a valid marriage bond. Still, without his knowledge and without obtaining permission or approval from the Applicant, it turns out that Salijo has remarried another woman named Nuryani Binti Sudarno (Respondent). There was only known by the Applicant more or less in January 2016 when the Applicant took care of Salijo's pension at the Taspen Surakarta Office, was from the data in the Office of Taspen Surakarta turned out to be recorded as a wife and get pension rights from Salijo is the Respondent. When Salijo conducted marriage with the Respondent, known to be an act against the law in the filing, Salijo mentioned that the Applicant has died as recorded in the Death Certificate No. 474.3/2 issued by the Government of Wanglu Village, Klaten Regency. As well as the inclusion of the name of Salijo's parents, in the Marriage Certificate, 
Citation Salijo's parents' name is written Siswo Sumarto when the actual name of Salijo's parents is Merto, while Siswo Sumarto is the brother-in-law of Salijo.

Based on the description above, the author will analyze identity forgery committed by the bride and groom, namely:

a. Falsifying Identities. In the Marriage between Salijo and the Respondent, Salijo forged an identity under Saliyo bin Siswo Sumarto. His real name was Salijo bin Merto, and the inclusion of Salijo's parents' name in the Marriage Certificate Citation was named Siswo Sumarto. Still, Salijo's parents' name was Merto, while Siswo Sumarto was the brother-inlaw of Salijo.

b. Falsifying Death Certificate. Based on the description above, Salijo mentioned that the Applicant has died as recorded in the Death Certificate No. 474.3/2 issued by the Wanglu Village Government. Salijo is a widower and can remarry the Respondent. But Salijo, until his death, the Applicant is still alive and in good health, fresh and fit.

The Applicant lives with his children and grandchildren. The legal consequences of identity forgery will lead to the annulment of marriage, which will have an impact on the separation between husband and wife due to the breakup of marriage due to divorce in article 41 of the Marriage Act, namely:

a. The mother or father remains obliged to nurture and educate his children solely based on the child's interests; when there is a dispute regarding children's possession, the Court gives its decision.

b. The father is responsible for all maintenance costs and education costs required by the child. If the father, in reality, is unable to meet the obligation, the Court can determine that the mother is responsible for the cost. The Court may require the ex-husband to provide the cost of living or define an obligation for the ex-wife.

c. Married without the permission of the first wife. The laws and regulations have stated that in a marriage, a man may only have a wife and a woman may only have a husband, but a husband may have more than one wife if there is permission from the Court and approval from the first wife. As the purpose of article 3, 4, 5, and 9 law No. 1 the year 1974 jo Article 56 and 58 Compilation of Islamic Law.

However, the marriage's implementation between Salijo and the Respondent is not included consent and permission from the first wife. As based on the provisions of Article 24 and 25 of Law No.1 of 1974 jo Article 71 paragraph 1 Compilation of Islamic Law the Marriage can be annulled, then the Marriage Certificate Number: 36/36/IV/96 dated April 22, 1996, issued by the Office of Religious Affairs Tirtomoyo Subdistrict is declared to have no legal force and does not bind the parties concerned Consideration of Judges in Granting The Application for Annulment of Marriage In the Decision that becomes the reference of the author is working on this thesis, according to the author two forms of consideration become the basis of care of the Judge in granting the application for annulment of marriage. Reflections of the Judge in granting the request for dissolution of the wedding are:

a. Fact Considerations. Considerations of facts used by the Judge to grant the application for annulment of the marriage are: First, the Applicant was married to Salijo bin Merto in 1969. During the wedding, he had never divorced until Salijo died in 2008. Second, without the Applicant's knowledge and permission, the Applicant's husband in 1996 has remarried to Nuryani Binti Atmo Sudarno by falsifying identity/data where Salijo claimed to be named Salijo bin Siswo Sumarto addressed in Wanglu Village, Tirtomoyo Subdistrict, Wonogiri Regency, even Salijo stated that the Applicant has died so that he can marry the Respondent with widower status. Third, the Applicant only learned of Salijo's Marriage with the Respondent in January 2016 when the Applicant took care of 
Salijo's pension at the Taspen Surakarta Office, apparently recorded as a wife in the Taspen Office is the Respondent.

b. Legal Considerations. In the legal considerations used by the Judge in granting the application for annulment of the marriage, namely: First, the enactment of Law No. 1 of 1974 provisions of Article 24 and Article 25 on marriage that explains that if the marriage is still tied to one of the parties and based on still the existence of marriage can apply for the annulment of a new marriage without prejudice to the provisions in Article 3 paragraph 2, and Article 4 as well as the application for dissolution of marriage submitted to the Court in the jurisdiction where the wedding is held or in the residence of both husband and wife, husband or wife. Article 71 paragraph 1 letter a Compilation of Islamic Law explains that a marriage can be annulled if a husband commits polygamy without the Court of Religion's permission.

Based on the above ruling, the Applicant is still bound to marry Salijo because since salijo is still alive until death, the Applicant has not divorced Salijo until Salijo remarried to the Respondent permission of the Court and the consent of his first wife. The application for annulment of the marriage can be canceled because the procedure of implementation of marriage is not per the law. Based on humanity and the interests of innocent children, it deserves legal protection. And it should not be if innocent children have to bear the consequences of not having parents, just because of the fault of their parents, thus according to Law No. 1 of 1974, the children born have a clear legal status as the legal children of both parents whose marriage is annulled.

\subsection{Legal Implications of Cancellation of Marriage Due to Identity Forgery at the Klaten Religious Court}

Marriage's annulment is if a marriage contract is not fulfilled or some pillars or conditions in the marriage are not valid. The invalidity of a marriage contract can occur because of the unfulfillment of one of the pillars called a void marriage contract. It can also happen because of the unfulfillment of one of the conditions called a valid marriage contract.

The pillars and conditions determine a legal action, especially concerning the validity or absence of such acts in terms of the law. Both words have the same meaning in that they are something that must be held. In a marriage ceremony, for example, get along well, and the conditions should not be left behind, in the sense of invalid marriage if both are not there or incomplete. Both have different meanings in that harmony is something that is, in fact, and is a part or element that suggests it, while the condition is something outside it and is not unsung. There are conditions related to harmony in conditions that apply to each component that becomes harmonious. There is also a condition that stands alone in the sense that it is not a criterion of harmony elements. (Amir Syarifuddin, 2011: 59)

The mating of more than one person is an exception. Also, this acquisition is provided with severe restrictions in the form of binding terms and objectives. In Article 27 paragraph (2) of the Marriage Act of 1974, it is said that: "a husband or wife can apply for annulment of marriage if there is a time when there is a misperception about the husband or wife." Thus, if a marriage in which one party is still bound by a valid marriage with the other party and does not have a polygamy license, it can be requested an annulment. As a result of the law, the annulled party is obliged to continue to provide for his ex-wife during her iddah period because of a marriage annulling. This is the time for a woman who is divorced from her husband to marry again to know the cleanness of her womb or to carry out Allah's command. As for the purpose and wisdom of the obligatory iddah, namely: 
a. To find out the cleanness of the woman's uterus from the seedlings left by her ex-husband

b. For tea bud, it means solely to fulfill God's will even though by ratio, we think there is no need anymore.

The wisdom that can be taken from the provision of the idah is that the husband who has divorced his wife thinks again and realizes it is not bai and sorry for his actions. With iddah, he can re-establish a married life without having to hold a new contract. The author also concluded that society's reality often occurs marriage without polygamy permission. The husband feels insufficient with a wife and because the number of women is more than men. This violates the Marriage Act No. 1 of 1974 and the compilation of Islamic Law.

\section{Conclusion}

In the Marriage between Salijo and the Respondent, Salijo forged an identity under Saliyo bin Siswo Sumarto. His real name was Salijo bin Merto, and the inclusion of Salijo's parents' name in the Marriage Certificate Citation was named Siswo Sumarto. Still, Saijo's parents' name was Merto, while Siswo Sumarto was the brother-in-law of Salijo. Based on the description above, Salijo mentioned that the Applicant has died so that Salijo is a widower and can remarry the Respondent. But Salijo, until his death, the Applicant is still alive and in good health, fresh and fit. The Applicant lives with his children and grandchildren.

The laws and regulations have stated that in a marriage, a man may only have one wife and a woman may only have a husband, but a husband may have more than one wife if there is permission from the Court and approval of the first wife. As the purpose of Article 3, 4, 5, and 9 law No. 1 of 1974 jo Article 56 and 58 Compilation of Islamic Law. But in the implementation of Marriage between Salijo and the Respondent is not included the consent and permission of the first wife. As based on the provisions of Article 24 and 25 of Law No.1 of 1974 jo Article 71 paragraph 1 Compilation of Islamic Law the Marriage can be canceled, then the Marriage Certificate Number: 36/36/IV/96 dated April 22, 1996, issued by the Office of Religious Affairs Tirtomoyo Subdistrict is declared to have no legal force and does not bind the parties concerned. Second, from the evidence, results can be found in legal facts: (a) The Applicant was married to Salijo bin Merto in 1955. During the marriage, she had never divorced until Salijo died in 2008. (b) Unbeknownst to and without the Applicant's permission, the Applicant's husband (Salijo) in 1996 has remarried to Nuryani Binti Atmo Sudarno by falsifying identity/data, where Salijo claimed to be named Saliyo Bin Merto Sumarto who is addressed in Wanglu Village, Klaten Regency, even Salijo stated that the Applicant has died so that he can marry the Respondent with widower status. The Applicant only learned of Salijo's Marriage to the Respondent in January when the Applicant took care of the retirement of $14 \mathrm{alm}$. Salijo in Taspen Surakarta Office recorded as a wife in the Taspen Office is the Respondent.

\section{References}

[1] Anwar, N. S. (2019). Analisis Transaksi Digital Cryptocurrency Sebagai Investasi Global Dalam Perspektif Hukum Islam (Studi Kasus Dinar Dirham di Makassar).

[2] Gordon, J. M. (1998). Business Law: An Introduction. Business Law: An Introductionby TheBusinessProfessor.Com, 501(c), 428-431. 
[3] Santiago, F. (2016). Bunga Rampai Catatan Hukum. Perpustakaan Nasional RI. Katalog Dalam Terbitan.

[4] Supriyanto, Eko Eddya. 2020. Eksistensi Nilai-Nilai Pancasila Dalam Kebijakan Ekonomi Indonesia. 1st ed. Malang: Literasi Nusantara.

[5] Supriyanto, E. E. (2021). Strategi Penerapan Kebijakan Sovereign Wealth Funds (SWFs) di Indonesia: Studi Literatur dan Studi Komparatif Oman. Jurnal Inovasi Ilmu Sosial Dan Politik (JISoP), 3(1), 10-21. https://doi.org/10.33474/jisop.v3i1.6959

[6] Supriyanto, E. E. (2018). Perang Strategi Pemenangan Pemilu Via Sosial Media (Sebuah Analisis Literatur Dan Sosial Media). In L. K. Alfirdaus \& N. Hasfi (Eds.), Proceeding Seminar Nasional dan Diskusi Ilmiah Media, Pemilu dan Komunikasi Politik Menyambut Tahun Politik Indonesia 2018-2019 (pp. 122-135). Magister Ilmu Politik FISIP Universitas Diponegoro.

[7] Nababan, K. N. N. (2019). Tinjauan Legalitas Transaksi Bitcoin di Indonesia. JuristDiction, 2(5), 1745-1764. 